\title{
AN AB INITIO MOLECULAR DYNAMICS STUDY OF HYDRATION STRUCTURE OF HYDROPHOBIC CHAIN-LIKE MOLECULES WITH SIDE HYDROPHILIC GROUPS*
}

\author{
T. M. Bryk, M. F. Holovko \\ Institute for Condensed Matter Physics, National Academy of Sciences of Ukraine, \\ 1 Svientsitskii St., UA-79011 Lviv, Ukraine
}

(Received January 31, 2007)

\begin{abstract}
Ab initio geometry optimization of a single molecule and Car-Parrinello molecular dynamics simulation for the hydrated molecule were applied in order to study hydration shell of a chain-like molecule $\mathrm{CH}_{3}-\left[\mathrm{CH}_{2}-\mathrm{CHOH}\right]_{n}-\mathrm{CH}_{2}-\mathrm{CH}_{3}$ with $n=2$ containing hydrophobic and side hydrophilic groups. The analysis of a partial pair distribution functions reveals that upon hydration each hydrophylic $\mathrm{OH}$ group has two neighbor water molecules oriented towards hydrogens and oxygens of hydrophilic groups. The hydration process causes essential changes of mutual orientation of hydrophilic groups in comparison with a free molecule case.

Key words: hydration structure, hydrophobicity, chain-like molecules, computer simulations, Car-Parrinello dynamics.

PACS number(s): 31.15.Ar, 33.15.Bh, 61.20.Ja, 82.20.Wt
\end{abstract}

\section{INTRODUCTION}

Molecular dynamics (MD) simulations are a useful tool to study structural and dynamical properties of complex systems on atomic level. Classical as well as Brownian MD are widely used for simulations of soft matter, protein folding and chemical processes in different environments [1]. The reliability of computer simulations crucially depends on effective two- or many-body potentials applied in modeling the interactions between real ions and molecules. Usually such effective potentials can be derived from quantum chemical calculations of small clusters: the effective charges of ions can be estimated from electron density distribution, and short-range parts of effective potentials should correctly reflect structural units of quantum calculations. An essential drawback of simulations based on the effective potentials between particles is the inability to take correctly into account covalent bonding and polarization effects in the system due to the fluctuations of electronic subsystem. These effects are extremely important in molecular systems, especially for large molecules with chain-like groups, the atoms of which usually must have different effective charges depending on instanteneous environment. An increasing power of parallel computers permits now to use $a b$ initio molecular dynamics simulations for the systems of 100500 atoms, in which electron density is treated within the density functional theory $[2,3]$. The main drawback of the ab initio simulations is a hardware limitation on the system size, because each atom brings into simulation several valence electrons, for which corresponding wave functions are calculated on each step of MD. Hence, wavefunction calculations and especially their orthonor- malization take a huge share of time of ab initio MD simulations and hence the simulations of large molecules on ab initio level are rather rare [4-6]. Usually one applies ab initio simulations to the study of systems composed of relatively small molecules.

The studies of the hydration structure of complex molecules, which contain hydrophilic and hydrophobic groups are of great interest because they can point out to the origin of conformation of chain-like molecules in solvents. Water itself is a complex molecular environment with hydrogen bond networks, which in contact with surfaces or large molecules can form specific interfacial regions with interesting structural and dynamical properties.

This paper is focused on ab initio study of the hydration structure of a chain-like molecule, which contains hydrophobic and side hydrophilic groups. The concurrence between hydrophobic and hydrophilic regions can cause essential changes in molecular geometry of the studied large molecules. An essential advantage of the ab initio approach over classical simulations and phenomenological approaches is a possibility of observing the microscopic processes on a subatomic scale, when the redistribution of electronic density causes Hellman-Feynman forces acting on ions and bringing them towards a configuration with minimal free energy. Precisely ab initio density functional approach permits a correct treatment of hydrogen bonding and polarization effects due to electronic density polarization, while the classical effective models may only approximately represent such processes.

In this study we investigate the geometry and hydration structure of the model $\mathrm{CH}_{3}-\left[\mathrm{CH}_{2}-\mathrm{CHOH}\right]_{2}-\mathrm{CH}_{2}-$ $\mathrm{CH}_{3}$ molecule, which exists as fragments in real organ-

* It is a great pleasure for us to dedicate this paper to Professor I. O. Vakarchuk for his 60th birthday celebration 
ic chain-like molecules like vinyl alcohols [7]. The main aim of this ab initio study is to find out how the two hydrophilic groups behave during hydration of such a molecule. The structure of the hydration shell of the chain-like molecule is studied by means of Car-Parrinello ab initio dynamics [2]. In the next Section we give details of our simulations, obtained results are discussed in Section 3, and conclusions of this study will be gathered in Section 4.

\section{DETAILS OF CALCULATIONS}

As the first step we have performed an electron density functional study of equilibrium geometry of single molecules $\mathrm{CH}_{3}-\mathrm{CH}_{2}-\mathrm{CHOH}-\mathrm{CH}_{2}-\mathrm{CH}_{3}$ and $\mathrm{CH}_{3}-\left[\mathrm{CH}_{2}-\right.$ $\mathrm{CHOH}]_{2}-\mathrm{CH}_{2}-\mathrm{CH}_{3}$. The calculations on the second type of molecule were needed in order to understand the tendency in geometry of the chain-like molecule with an increasing number of $\left[\mathrm{CH}_{2}-\mathrm{CHOH}\right]$ groups. Starting from the very simple flat initial configuration of $\mathrm{CH}_{3}-\mathrm{CH}_{2}-\mathrm{CHOH}-\mathrm{CH}_{2}-\mathrm{CH}_{3}$ with all almost $90^{\circ}$ and $180^{\circ}$ angles and $1-1.5 \AA$ distances between atoms we have turned on density functional minimization and have obtained an equilibrium three-dimensional structure of this single molecule in good agreement with distances and angles parameterized by Jorgensen et al [8]. Gradient-corrected Perdew-Burke-Ernzerhof (PBE) [9] energy functional with Vanderbilt ultrasoft pseudopotentials [10] and a plane-wave cutoff energy of 25 Ry were used. The initial atomic configuration for the molecule $\mathrm{CH}_{3}-\left[\mathrm{CH}_{2}-\mathrm{CHOH}\right]_{2}-\mathrm{CH}_{2}-\mathrm{CH}_{3}$ was constructed from the output $\mathrm{CH}_{3}-\mathrm{CH}_{2}-\mathrm{CHOH}-\mathrm{CH}_{2}-\mathrm{CH}_{3}$ configuration by adding another $\left[\mathrm{CH}_{2}-\mathrm{CHOH}\right]$ fragment with different orientations of $\mathrm{OH}$ groups and subsequent energy minimization. The lowest total energy obtained in geometry optimization was obtained for the configuration with almost parallel $\mathrm{OH}$ groups (Fig. 1).

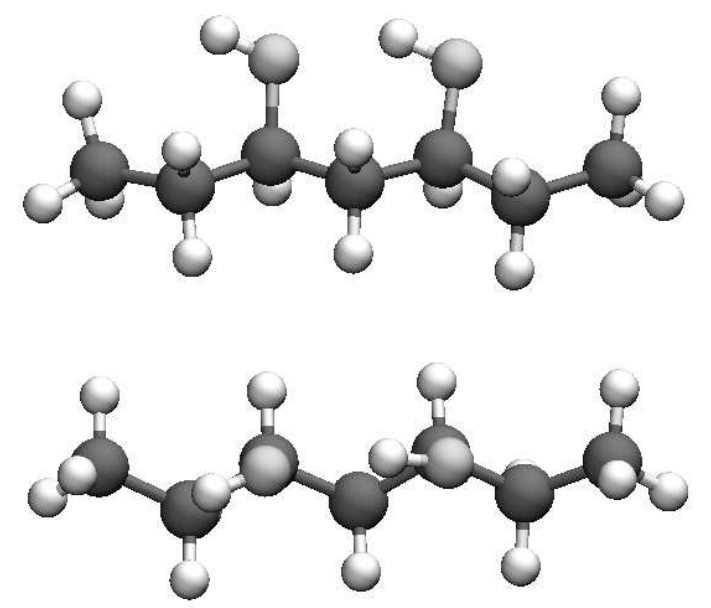

Fig. 1. Geometry of a single molecule $\mathrm{CH}_{3}-\left[\mathrm{CH}_{2}-\mathrm{CHOH}\right]_{2}$ $-\mathrm{CH}_{2}-\mathrm{CH}_{3}$ obtained in density functional minimization: side view (upper configuration) and top view (bottom configuration). Black, dark grey and light gray spheres represent carbons, oxygens and hydrogens, respectively.
In the second step the output $\mathrm{CH}_{3}-\left[\mathrm{CH}_{2}-\mathrm{CHOH}\right]_{2}^{-}$ $\mathrm{CH}_{2}-\mathrm{CH}_{3}$ molecule was hydrated by 40 water molecules. At first we made geometry optimization for the whole system of 145 atoms, and later started Car-Parrinello molecular dynamics in the NVT ensemble with the reference temperature of $293 \mathrm{~K}$ provided by Nose thermostat. The electronic subsystem of doubly occupied 188 states was kept at the ground state by means of the standard in NVT Car-Parrinello technique of electronic thermostating with a low reference electronic kinetic energy. Time step in the Car-Parrinello simulations was 5 a.u., and production run was of 2.5 ps. Each second configuration was taken for estimation of partial distribution functions. All ab initio simulations were performed by the standard CPMD package [11].

\section{RESULTS AND DISCUSSION}

We have performed the static geometry optimization of the separate molecule $\mathrm{CH}_{3}-\left[\mathrm{CH}_{2}-\mathrm{CHOH}\right]_{2}-\mathrm{CH}_{2}-\mathrm{CH}_{3}$ via density functional minimization over almost four hundred optimization steps unless the energy was converged within a standard level of one $\mathrm{meV}$. The obtained structure is shown in Fig. 1 (side and top view). One can see, that two hydrophilic groups are almost parallel, there exists a small angle of $17^{\circ}$ between the two $\mathrm{OH}$ groups. The other important distances and angles were obtained as follows: $r_{\mathrm{OH}}=0.980 \pm 0.005 \AA, r_{\mathrm{OC}}=1.44 \pm 0.01 \AA$, $r_{\mathrm{CH}}=1.100 \pm 0.005 \AA, r_{\mathrm{CC}}=1.533 \pm 0.005 \AA, \angle \mathrm{HOC}=$ $107^{\circ} \pm 1^{\circ}, \angle \mathrm{CCC}=114^{\circ} \pm 2^{\circ}, \angle \mathrm{HCH}=107.5^{\circ} \pm 1^{\circ}$.

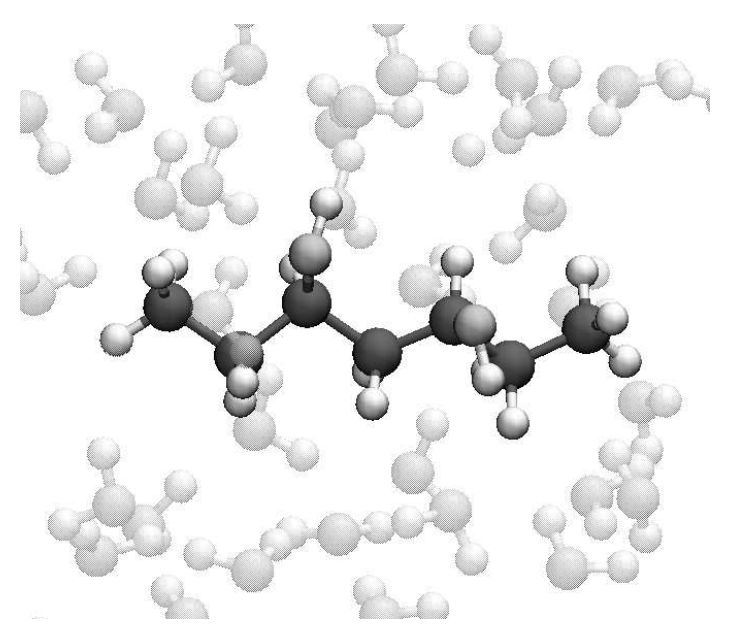

Fig. 2. A snapshot of hydrated chain-like molecule $\mathrm{CH}_{3}-\left[\mathrm{CH}_{2}-\mathrm{CHOH}\right]_{2}-\mathrm{CH}_{2}-\mathrm{CH}_{3}$. Water molecules were shadowed in order to highlight the chain-like molecule. Due to hydration the hydrophilic groups reorient with respect to the non-hydrated state.

Upon static hydration of the molecule $\mathrm{CH}_{3}-\left[\mathrm{CH}_{2}-\right.$ $\mathrm{CHOH}]_{2}-\mathrm{CH}_{2}-\mathrm{CH}_{3}$ and subsequent equilibration run of Car-Parrinello molecular dynamics we have started to calculate partial site-site distribution functions between 
atoms of water molecules (W) and atoms of the chainlike molecule. Immediately after bringing the chain-like molecule into contact with water molecules we observed changes in the mutual orientation of the two hydrophilic groups. One can see in Fig. 2 a snapshot of the hydrated $\mathrm{CH}_{3}-\left[\mathrm{CH}_{2}-\mathrm{CHOH}\right]_{2}-\mathrm{CH}_{2}-\mathrm{CH}_{3}$ molecule, in which due to the interaction with water molecules the hydrogens of the hydrophilic groups are headed almost in opposite directions. Three main partial pair distribution functions $g_{i j}(r)$ shown in Figs. $3 \mathrm{a}-\mathrm{c}$ provide one with a complete information about hydration shell in the vicinity of the two hydrophilic groups. Due to a small number of hydrophilic groups, statistics is not high that is reflected in a noisy behaviour of the partial pair distribution functions, although the estimation of running coordination numbers was performed without complications.
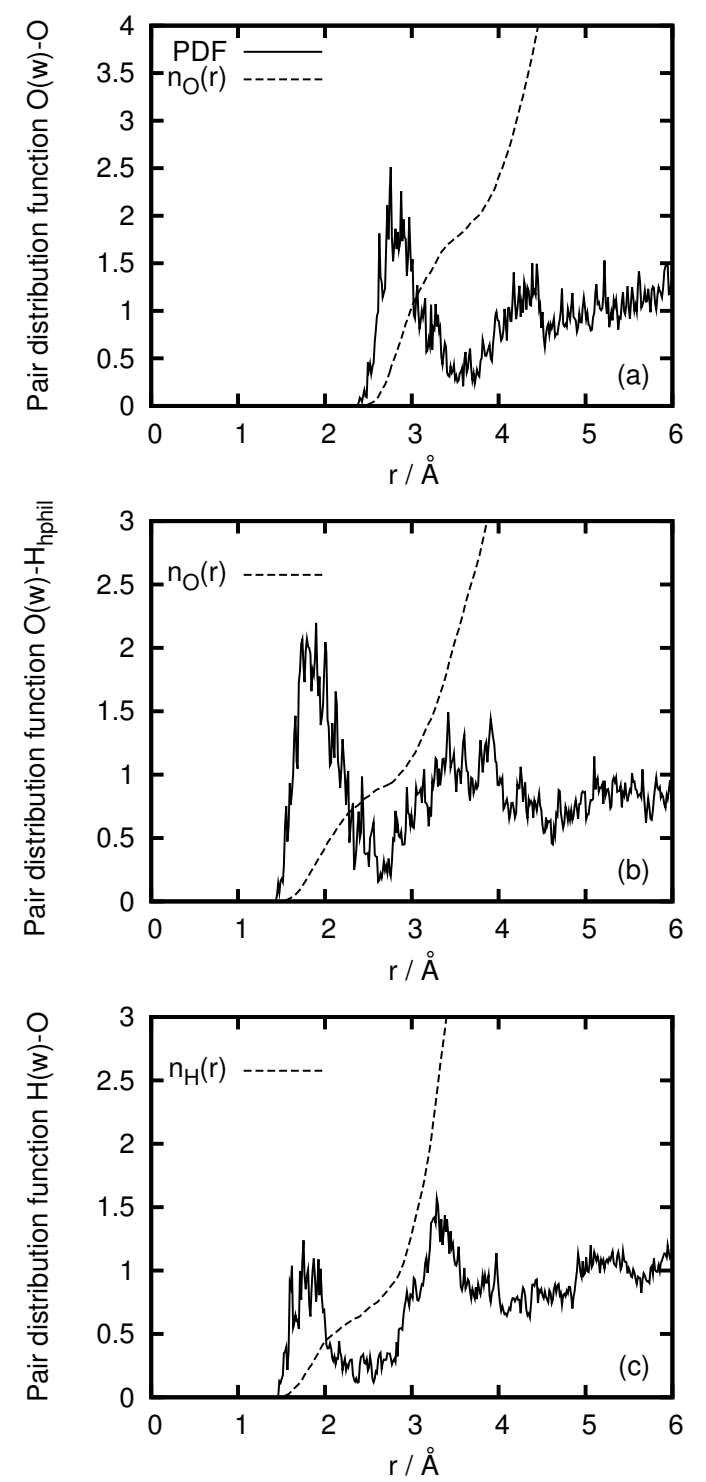

Fig. 3. Partial pair distribution functions: $\mathrm{O}(\mathrm{W})-\mathrm{H}(\mathrm{a})$ and $\mathrm{O}(\mathrm{W})-\mathrm{O}(\mathrm{b})$ between oxygens of water molecules and atoms of hydrophilic groups; $\mathrm{H}(\mathrm{W})-\mathrm{O}$ (c) between hydrogens of water molecules and oxygens of hydrophilic groups. By dashed line the corresponding running coordination numbers are shown.
For the case of distributions of $\mathrm{O}(\mathrm{W})-\mathrm{H}_{\text {hphil }}$ (hydrogens of hydrophilic groups only), $\mathrm{O}(\mathrm{W})-\mathrm{O}$ and $\mathrm{H}(\mathrm{W})-\mathrm{O}$, the corresponding running coordination numbers $n_{W}(r)$ reflect that in the vicinity of each hydrophilic group there reside two water molecules (Fig. $3 \mathrm{~b}$ ). In general we observe that one water molecule per hydrophilic group approaches by its hydrogens the oxygens of the hydrophilic groups as close as $\approx 1.5-2 \AA$ while the otber water molecule approaches by its oxygen the hydrogens $\mathrm{H}_{\text {hphil }}$ at the same distance. Since the first minimum of the pair distribution function $\mathrm{O}(\mathrm{W})-\mathrm{O}$ at $3.6 \AA$ does not drop to zero, it makes the evidence that the water molecules in contact with hydrophilic groups can be swaped by the bulk water molecules. In Fig. 4 we show a snapshot in which only four water molecules near hydrophilic groups are shown. The distances in Ångströms in Fig. 4 denote the nearest separation along the dashed lines that completely supports our analysis of partial pair distribution functions.

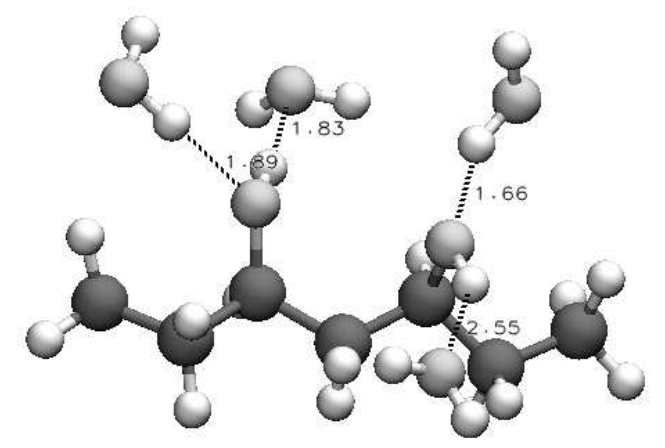

Fig. 4. A snapshot of nearest two water molecules near hydrophilic groups of the molecule $\mathrm{CH}_{3}-\left[\mathrm{CH}_{2}-\mathrm{CHOH}\right]_{2}$ $-\mathrm{CH}_{2}-\mathrm{CH}_{3}$. Dashed lines show the nearest distances (in Ångströms) to water molecules.

The effect of hydrophobicity is seen from Fig. 5, in which the partial distribution function between oxygens of water molecules and carbons is shown. Hydrophobic groups do not permit oxygens of the water molecules to approach to carbons closer than $3 \AA$.

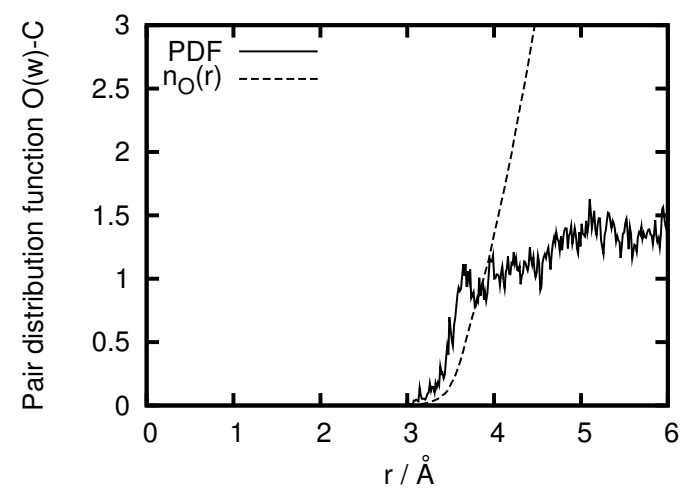

Fig. 5. Partial pair distribution function $\mathrm{H}(\mathrm{W})-\mathrm{C}$ between hydrogens of water molecules (W) and carbons of the hydrophobic groups. 
Another interesting feature of the hydration shell of the $\mathrm{CH}_{3}-\left[\mathrm{CH}_{2}-\mathrm{CHOH}\right]_{2}-\mathrm{CH}_{2}-\mathrm{CH}_{3}$ molecule is the striking evidence of the change in mutual orientation of both hydrophilic groups of the chain-like molecule upon hydration. Then the angle between the two $\mathrm{OH}$ groups changes essentially. The water molecules in the hydration shell force the hydrophilic groups to reorient and have the angle between both $\mathrm{OH}$ directions slowly changing between $100^{\circ}$ and $180^{\circ}$. Hence, one may conclude, that the water molecules from the hydration shell can change the initial geometry of a single chain-like molecule with several hydrophilic groups.

\section{CONCLUSIONS}

In this study we have investigated by ab initio MD computer simulations the equilibrium structure of a single $\mathrm{CH}_{3}-\left[\mathrm{CH}_{2}-\mathrm{CHOH}\right]_{2}-\mathrm{CH}_{2}-\mathrm{CH}_{3}$ molecule as a model chain-like molecule containing hydrophobic and side hydrophilic groups. We were able to obtain equilibrium geometry of the single chain-like molecule from ab initio density functional minimization in good agreement with
Jorgensen's parameters for interatomic distances and angles in organic molecules.

Upon hydration we observed a change in orientation of hydrophilic $\mathrm{OH}$ groups of the $\mathrm{CH}_{3}-\left[\mathrm{CH}_{2}-\mathrm{CHOH}\right]_{2}-$ $\mathrm{CH}_{2}-\mathrm{CH}_{3}$ molecule. The static minimization of hydration structure and subsequent dynamical simulations resulted in approximately $138^{\circ}$ angle between the two $\mathrm{OH}$ groups. The analysis of the running coordination numbers implies, that obtained at $T=293 \mathrm{~K}$ and over 2.5 ps Car-Parrinello molecular dynamics run site(W)site pair distribution functions make evidence that two water molecules can approach each hydrophilic group, and this perhaps is responsible for their mutual reorientation.

This study is the first step in initio simulations of the hydration shells of chain-like molecules with hydrophobic and side hydrophilic groups that we started recently. The following studies will be focused ugon the dependence of geometry changes in hydrated chain-like molecules $\mathrm{CH}_{3}-$ $\left[\mathrm{CH}_{2}-\mathrm{CHOH}\right]_{n}-\mathrm{CH}_{2}-\mathrm{CH}_{3}$ on the chain length.

\section{Acknowledgements}

This research was partially supported by the STCUNASU Project No. 4140. All calculations were performed on the ICMP cluster.
[1] D. Frenkel, B. Smit, Understanding Molecular Simulation (Academic, San Diego, 2001).

[2] R. Car, M. Parrinello, Phys. Rev. Lett. 55, 2471 (1985).

[3] M. C. Payne, M. P. Teter, D. C. Allan, T. A. Arias, J. D. Joannopoulos, Rev. Mod. Phys. 64, 1045 (1992).

[4] M.-P. Gaigeot, M. Sprik, J. Phys. Chem. B 107, 10344 (2003).

[5] M.-P. Gaigeot, R. Vuilleumier, M. Sprik, D. Borgis, J. Chem. Theor. Comput. 1, 772 (2005).

[6] D. C. Marinica, G. Gregoire, D. Defrancois, J. P. Schermann, D. Borgis, M.-P. Gaigeot, J. Phys. Chem. A 110, 8802 (2006).
[7] I. Piirma Polymeric surfactants. Surfactant science series: v. 42. (Marcel Dekker, New York, 1992).

[8] W. L. Jorgensen, J. D. Madura, C. J. Swenson. J. Am. Chem. Soc. 106, 6638 (1984); W. L. Jorgensen, D. S. Maxwell, J. Tirado-Rives, J. Am. Chem. Soc. 118, 11225 (1996).

[9] J. P. Perdew, K. Burke, M. Ernzerhof, Phys. Rev. Lett. 77, 3865 (1996)

[10] D. Vanderbilt, Phys. Rev. B 41, 7892 (1990).

[11] CPMD V.3.9 Copyright IBM Corp.1990-2004, Copyright MPI für Festkörperforshung, Stuttgart, 1997-2001.

\title{
ДОСЛІДЖЕННЯ ГІДРАТНОЇ СТРУКТУРИ ГІДРОФОБНИХ ЛАНЦЮГОВИХ МОЛЕКУЛ З БОКОВИМИ ГІДРОФІЛЬНИМИ ГРУПАМИ ЗА ДОПОМОГОЮ МЕТОДУ ПЕРШОПРИНЦИПНОЇ МОЛЕКУЛЯРНОЇ ДИНАМІКИ
}

\author{
Т. М. Брик, М. Ф. Головко \\ Інститут фізики кондесованих систем НАН України \\ вул. Свенцічького, 1, Львів, 79011, Україна
}

\begin{abstract}
Першопринципна оптимізація геометрії окремої молекули та моделювання гідратованої молекули методом молекулярної динаміки Кар-Паррінелло були застосовані для дослідження гідратної структури ланцюгових молекул $\mathrm{CH}_{3}-\left[\mathrm{CH}_{2}-\mathrm{CHOH}\right]_{n}-\mathrm{CH}_{2}-\mathrm{CH}_{3}$ з $n=2$, що містять гідрофобні та бокові гідрофільні групи. Аналіз парціяльних парних функцій розподілу вказує на гідратацію кожної гідрофільної ОН-групи двома молекулами води, що орієнтовані в бік воднів та киснів гідрофільних груп. Процес гідратації спричиняє суттєві зміни у взаємній орієнтації гідрофільних груп порівняно з випадком окремої молекули.
\end{abstract}

